\title{
Adaptive Reuse of the Industrial Building: A case of Energy Museum in Sanatistanbul, Turkey
}

\author{
MA. Najmaldin Hussein
}

Department of Architecture, Faculty of Architecture, Eastern Mediterranean University, Turkey

\section{ART ICLEINF O: \\ Article history: \\ Received 20 September 2016 \\ Received in revised form 5 \\ December 2016 \\ Accepted 20 January 2017 \\ Available online 2 January \\ 2017}

\section{Keywords:}

Industrial Building;

Adaptive Reuse;

Conservation methods;

Energy Museum;

Gentrification;

Sanatistanbul.

\begin{abstract}
A B S T R A C T
Industrial buildings as an example of cultural heritage transforms our cultural identity from past to the present and even for the future. Unfortunately, there are lots of industrial building which lost its function by converting the place to live and identifiable place. This research will clarify the reasons of conserving of the industrial heritage and by classification of international charters which are dealing with industrial heritage will introduce conservation methods for adaptive reuse of industrial buildings. As a case study, the research will focus on Energy Museum in Istanbul. To assess the building based on reusing principals. The study concludes that Energy Museum is one of the successful examples of reuse of the building. It also concludes that less intervention in reusing a building can save the identity of the building.
\end{abstract}

JOURNAL OF CONTEMPORARY URBAN AFFAIRS (2017) 1(1), 24-34.

https://doi.org/10.25034/1761.1(1)24-34

\footnotetext{
This work is licensed under a Creative Commons Attribution NonCommercial - NoDerivs 4.0. "CC-BY-NC-ND"
}

\section{Introduction}

\subsection{A History of the concept of Industrial Heritage}

The idea of Industrial Heritage $(\mathrm{IH})$ hosted for a first time in England in the middle of the $12^{\text {th }}$ century, when several landscapes and industrial buildings were demolished (Kuhl, 2004). Then the idea of "heritage" traversed from the borders of the industrialized districts, by affecting from the past which is quite prominent to the present (Choay, 1992). From that time till contemporary era, there were many efforts and conferences to describe what it needs to do with conservation of industrial heritage. Considering Nizhny Tagil (NT) Charter "the industrial heritage consists of the remains of industrial culture which are of historical,

\section{*Corresponding Author:}

Department of Architecture, Faculty of Architecture, Eastern Mediterranean University, Gazimagusa, via Mersin 10, Turkey E-mail address: najmaldin.hussein@gmail.com 
technological, social, architectural or scientific value" (TICCIH, 2003).

According to Burley and Loures (2008) architectural heritage and landscape heritage are the center of social, cultural, unique spiritual values. In the past, there was different understanding in each generation it also derives new stimulation from it to build a capital in social contribution through the centuries (ECH, 1975). Selfslagh (2002) states that it is impossible to rebuild or renew the cultural heritage. The reason for that is no way to rebuild cultural heritages which already destroyed. Therefore, industrial heritage which is part of cultural heritage needs specific consideration to preserve by transforming its authenticity to our future generation. Cultural heritage as part of our past history, which belongs to our ancestors should be preserved. Industrial heritage which doesn't work anymore needs to preserve to get benefits from Initial capital for different purpose of social and capital activities. In this regard conservation of industrial heritage will be the best method to preserve in order to give sprite to the context.

\section{Conservation of Industrial Heritage ( $\mathrm{ClH})$}

The idea of $\mathrm{ClH}$ started from 1950th century and introduced by Michael Rix (1955). Also the same discussion previously clarified in the 18th century with the concept of conservation on the architecture of the building production and equipment. In this regard, in Britain in 1973 there were first congers of $\mathrm{ClH}$ and also conservation of an industrial monument to evaluate and develop the historic culture and value of industrial heritage (Trinder, 1992). Consequently, the researchers from non-governmental organization established to focus on this subject. Right after Iron bridge congress (meeting) The International Committee for the Conservation of the Industrial Heritage which is known as $\mathrm{TICCIH}$ was founded. The international associations such as UNESCO and ICOMOS also established with the aim of conservation and specially by focusing of $\mathrm{ClH}$. ICOMOS in his description of industrial heritage mentioned to social, cultural and technical values of industrial heritage considered as a complimentary part of collective memory for this reason it's needed to preserve. The main aim of establishment of $\mathrm{TICClH}$ was also to conserve industrial heritage $(\mathrm{IH})$

$\mathrm{TICCIH}$ was recognized in 1974 for preservation of artefacts and industrial heritage and artefacts by studying its educational, historical, scientific, and cultural values. Later, from 1970 th the term IH have been used in Eastern European Countries. The term has been used in France with the title of Heritage. In Holland in the period of 1986 the collection center for international industrial was established. "The organizations regulations and the investigations were constituted in Scandinavian Countries" (Şimsek, 2006).

Considering the definition of $\mathrm{IH}$ in The Charter of Nizhny Tagil it refers to the conservation of objects and buildings as well as social services and production facilities (Nizhny Tagil Charter for the Industrial Heritage, 2003). In this regard, by considering intangible and tangible values in cultural heritage how to preserve and what we should preserve are the important questions which needed to be discussed. According to the Charter of Venice (1964) "It is vital that the principles guiding the preservation and restoration of ancient buildings should be agreed and be laid down on an international basis, with each country being responsible for applying the plan within the framework of its own culture and traditions." In the conservation, industrial heritage the idea isn't also referring to objective adjustment and organization of places, but it also refers to idea of contribution of conservation by enhancing the sense of place.

After the introducing of the term "Sustainable development" the idea of conservation of industrial heritage developed to use the social, cultural, economical benefits of a site. Demolished cultural heritage might increase the rate of crime, it also creates lost space which people might lose social connection and vitality of space in that area. According to the above discussion, it seems that the conservation of industrial heritage is mandatory which is parallel with the aim and objectives of sustainable development. In this regard, reuse of industrial heritage might be parallel to the aim of conservation. Following paragraph will describe 
the term reuse as a method for conservation of industrial heritage.

\section{Adaptive Reuse as a part of conservation of Historic Buildings (HB)}

Reuse of an industrial heritage in to new function will help to reduce sprawl reduction and land conservation. Turker (2013) believes that "reuse of HB will effect directly to community growth, their histories and leading to a minimal impact on the environment" (Turker, 2013). According to the literature studied in this research reusing of $\mathrm{HB}$ can be considered as a one of the best methods in preservation and conservation of $\mathrm{HB}$ in each and every context. According to Cascal (2007) after the process of reuse in $\mathrm{HB}$, it will get the new sprit rather than demolishing or being left to decades.

During the process of reuse for HB to completely new function, the process of renovation will add new layers to the history of the building. But according to Bullen et al., (2006) it's necessary mention that in the process of adding new functionality or layers to the HB the initial layers as an identity and history of the building should be preserved. It will also help to HB to keep its previous identity which belongs to certain period and time. Therefore, after reusing HB the sense of historical building still needs to be filled in reused building.

Consequently, according to Shipley (2006) reuse of $\mathrm{HB}$ is the most inventive and remarkable action which could be given to an old decaying HB. "The conservation process should maintain the cultural significance of a HB and interferences should be combined with the whole while, retaining its integrity and character" (Hurol et al., 2015).

Intervention in reusing the building for the new unction will need different methods by considering the environmental context of $\mathrm{HB}$. In this regard the new intervention and facilities to HB should adopt slightly juxtapose with the identity and character of HB. According to Orbasli (2009) if the reused functional effect the identity of the building or completely changed the identity and character of $\mathrm{HB}$ we can say that the reuse is not appropriated.

Figure 1 which developed base on City of Petersburg City code (2007) reveals that reusing industrial building are appropriate with any kind of functions without residential. Since the scale of an industrial building is bigger that residential building it will create many problems in the context which completely will change the identity of HB.

\begin{tabular}{|l|l|}
\hline $\begin{array}{c}\text { If the building or structure is located in } \\
\text { the following districts: }\end{array}$ & $\begin{array}{c}\text { The building or structure may be } \\
\text { used for the following : }\end{array}$ \\
\hline Neighborhoods, Traditional and Suburban & $\begin{array}{l}\text { All uses allowed in the district plus } \\
\text { multi-family uses and bed and } \\
\text { breakfasts. }\end{array}$ \\
\hline Corridor, Residential & $\begin{array}{l}\text { All uses allowed in the district plus any } \\
\text { allowable use in the NT-4 district }\end{array}$ \\
\hline Corridor, Commercial & Any use \\
\hline Centers, Traditional and Suburban & Any use \\
\hline Industrial & Any non-residential use \\
\hline
\end{tabular}

Figure 1. Chart of Reuse (City of Petersburg, City code, 2007).

According to Armesto González (2006) in order to reuse HB it needs suitable assessment of its context and situation of it in order to introduce a method of conservation to plan for its exploitation and recuperation.

In his research Fuentes (2010) proposed a method to reuse HB. He developed his method in six successive steps. The method which he developed is universal and could be applicable to different types of $\mathrm{HB}$ e.g. industrial, social, and residential and etc. Figure 2 illustrates the six main steps of assessing and documenting of $\mathrm{HB}$.
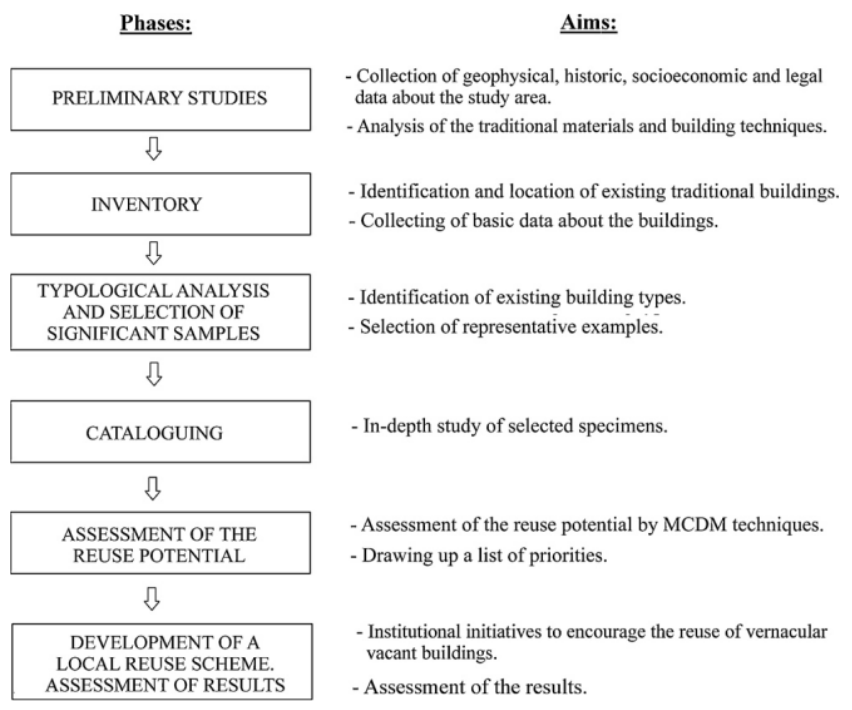

Figure 2. Process of documenting HB (Fuentes, 2010). 


\section{A study on international documents and charters and in the meaning of adaptive reuse}

The origins of stabilising of awareness for international practice and codes for conservation starts from a conference in Athen in 1931 which organized by international museum office. The origins of Venice charter is rooted in Athens charter comes from the $2^{\text {nd }}$ congress of architects and technicians of historic monument which held in Venice 1964.

International Council on Monuments and Sites is an association which works on technology, methodology, and theory of conservation of historic sites, historic areas and even historic buildings.

The idea of Venice charter taken in 1956 from International Council on Monuments and Sites (ICOMOS) is considered as one of the important charters of the conservation movement. It highlights the importance of context of the original context by documentation of any adjustment and by mentioning the importance of the new layer which add during the conservation process. Therefore, conservation in a way that to create socially useful environment in order to increase vitality of the context is the important concept in Venice charter. This charter forms the basic principles of conservation in contemporary approaches. On the official website of UNESCO all principals and roles in conservation regarding to Venice charter have been distributed.

The Florence Charter on Historic Gardens (1982) have been accepted by ICOMOS. The idea of developing a Florence Charter on Historic Gardens (FCHG) delivers the rules and principals of regeneration of historic garden and assessment of architectural building and landscape heritage.

The necessity of identifying, classifying and listing the historical gardens in order to prepare a context for philosophical guidance on conservation, maintenance and reconstruction and restoration. The principals for Florence Charter somehow following Venice Charter from the rules and principals of conservation point of view.Another charter CHTA' (1987) reflects comprehensive principals for protection and planning of historic urban areas.

In the 1990 there the charter for the Protection and Management of the Archaeological Heritage (CPMAH) have been established. The main aim of the charter was to consider: international cooperation, presentation, re-construction maintenance and conservation, legislation, survey in archaeological site and building and even industrial building. Consequently, in 1976 The Charter on Cultural Tourism tried to assess the negative and positive of cultural tourism on historic sites and monuments.

The Australian ICOMOS Charter known as The Burra Charter (1981) developed the rules and principals of Venice charter to be adoptable with local Australian supplies. The Burra Charter contains inclusive descriptions on rules of conservation and preservation. Place, maintenance, compatible use, adaptation, restoration and reconstruction. It also highlights the idea of cultural significance, the aesthetic of historical context, social and scientific values of the present, past and future generations. The Burra Charter is well established in Australia and is frequently used by the Australian Government in its formal capacity.

Another charter which is famous to New Zealand charter or charter for the Conservation of Places of Cultural Heritage Value prepare an opportunity to clarify the process of conservation to prepare principals to direct the conservation of historical context and buildings in New Zealand. Even the New Zealand charter follows in ides and rules of conservation from Venice Charter. The following paragraph prepares an opportunity to focus on the charters which were specially working with the idea of industrial heritage.

Considering the description and classification on conservation there are different charters which referring on conservation of IH.As Mannon (2004) Stated "As these industrial heritages are valuable and dealing specifically with buildings and artefacts of industry. There are different institutions have been emerged, working for keeping and protecting these $\mathrm{IH} . "$

\footnotetext{
${ }^{1}$ Charter on the Conservation of Historic Towns and Areas
} 
UNESCO, ICOMOS, ICCROM, $\mathrm{TICCIH}$, and AIA are the institutes which are on the conservation and preservation of $\mathrm{IH}$.

Table 1. Institutions Working on Conservation of Industrial Heritage (Developed by Author).

\begin{tabular}{|c|c|}
\hline \multicolumn{2}{|c|}{ Institutions Working on Conservation of Industrial Heritage } \\
\hline $\begin{array}{l}\text { TICCIH } 1973 \\
\text { The International Committee for } \\
\text { the Conservation of the Industrial } \\
\text { Heritage. }\end{array}$ & $\begin{array}{l}\text { - An international society dedicated to the study of industrial } \\
\text { archacology and the protection, promotion and interpretation of the } \\
\text { industrial heritage. } \\
\text { - It is ICOMOS scientific committee for industrial heritage. }\end{array}$ \\
\hline $\begin{array}{l}\text { ICOMOS } 1965 \\
\text { International Council on } \\
\text { Monuments and Sites }\end{array}$ & $\begin{array}{l}\text { - Works for the conservation and protection of cultural heritage } \\
\text { places around the world. } \\
\text {-It is a result of the Venice Charter of } 1964 \text {. } \\
\text { - ICOMOS has striven to promote the conservation ethic in all its } \\
\text { activitics and to help enhance public appreciation of humanity's } \\
\text { material heritage in all its forms and diversity. }\end{array}$ \\
\hline $\begin{array}{c}\text { ICCROM } \\
\text { An intergovernmental } \\
\text { organization dedicated to the } \\
\text { conservation of cultural heritage. }\end{array}$ & $\begin{array}{l}\text { - ICCROM aims at improving the quality of conservation practice } \\
\text { as well as raising awareness about the importance of preserving } \\
\text { cultural heritage. } \\
\text { - It is the only institution of its kind with a worldwide mandate to } \\
\text { promote the conservation of all types of cultural heritage, both } \\
\text { movable and immovable. }\end{array}$ \\
\hline $\begin{array}{c}\text { UNESCO } \\
\text { United Nations Educational, } \\
\text { Scientific and Cultural } \\
\text { Organization }\end{array}$ & $\begin{array}{l}\text { - The mission is to build the defences of peace in the minds of men. } \\
\text { - The Constitution was adopted by the London Conference in } \\
\text { November } 1945 \text {. }\end{array}$ \\
\hline $\begin{array}{c}\text { AIA } \\
\text { preservation and presentation of } \\
\text { Britain's industrial heritage }\end{array}$ & $\begin{array}{l}\text { - The national organization for people who share an interest in } \\
\text { Britain's industrial past. } \\
\text { - It brings together people who are researching, recording, } \\
\text { preserving and presenting the great variety of this country's } \\
\text { industrial heritage. } \\
\text { - Industrial architecture, mineral extraction, heritage-based tourism, } \\
\text { power technology, adaptive re-use of industrial buildings and } \\
\text { transport history are just some of the themes being investigated by } \\
\text { the members. }\end{array}$ \\
\hline
\end{tabular}

\section{Museums and their contribution to development of cultural heritage}

To understand and evaluate cultural identity and knowledge of our heritage museums play a significant role. ICOM (2007) describes museums as "as a non-profitable, permanent institution which acquires, preserves, studies, exhibits and disseminates the intangible and tangible inheritance of manhood for regeneration study, regeneration purposes, education".

Therefore, to find a way to transformation of values and by defining a knowledge in behind of heritage is the main aim of establishing a museum.

There are lots of methods to gain the main aim and objectives of establishing museums such as communication and information technology organization of exhibition spaces, educational actions, research tools. Designing a museum could be in such a way to organise either in open spaces or buildings. Therefore, based on the aim and objectives of each and every museums it can be organized and designed. Consequently, industrial building or even traditional residential building could also organize in such a way to define museums.

In designing a museum not only the mission of design important, but also it needs to consider to guaranty and consider the values and reservation techniques. Similarly, the protection of the construction should prevail above, the use of the museum with a particular aim.

In reusing a building for the museum we should also consider market value from the financial viewpoint. Therefore, aggregated value of the investment previously have been done.

Cultural heritage as a part of history which shows the culture and values of our traditional heritage needs somehow to preserve in such a way that to transform the cultural values from the past to the present and even for the future generation. In conservation of such building's reuse is the most important method. The reason for that refers to the already designed and constructed building infrastructure. Therefore, it also economically reasonable. The idea also can work in the revitalization of industrial heritage to increase the vitality and the liability of the context.

\section{Case study}

\subsection{Golden Horn as an important industrial region of Istanbul}

Until 1980s Golden Horn was vital industrial region, but after that there was some parallel process movement, such as deindustrialization and neoliberalization the property renovation concept start to effect of the organization principals and the master plan of the city.

Golden Horn as one in the old manufacturing area was the main purpose of interfering. But nowadays the area by using new strategies, counting large and more scale private speculation.

The Golden Horn divides the European part of Istanbul into historical peninsula or the old center and Beyoğlu (Pera). (Yerliyurt and Hamamcioğlu, 2005).

\footnotetext{
2 The International Council of Museums
} 
From 1960s Golden Horn involved great industrial facilities and continued the process of industrialization by enticing small-scale manufactures till 1980s.

"The decentralization of the industrial landscape that took place late in the $20^{\text {th }}$ century, along the shores of the Golden Horn and the valley beyond did not come about impulsively. Starting in the 1980s, industrial amenities were obligatory to abandon the Golden Horn and relocate to the margin of the city following new planning resolutions originating from istanbul's municipal authorities" (Yerliyurt and Hamamcioğlu, 2005).

As it is shown in figure 3 in the Golden Horn district, there are lots of industrial building which is valuable and counts as industrial heritage. Since basing on nowadays principals of urban development and master plan of Istanbul it is forbidden to build

\subsection{Santrallstanbul as a New Way of Interpretation of the Industrial Heritage}

At the end part of the golden horn from the north side there is the first power plant of the Ottoman Empire with the name of Santralistanbul (Silahtarağa Power Plant) which used to be the first power plant of the Ottoman Empire, which have been built in 1910 and was in operation until 1984.Santralistanbul has been fully re-functioned and conserved. Which is an art and cultural complex. Santralistanbul is containing of an energy museum, an amphitheatre, a modern art museum, concert halls and a public library which is situated within the Silahtarağa campus of Bilgi University, Istanbul (AKSOY, 2007). The Silahtarağa power plant was the first urban-scale power plant of the Ottoman Empire, founded in the Golden Horn district. It used to prepare electricity to Istanbul from 1914 until 1983.

The main reason for designing this area for producing electricity come be in the vicinity of the area to the other industrial manufactures which were in need of electricity (BRANGAR, 2004). indusial manufactures in these districts therefore it's not possible to use these buildings with the same function. Therefore, they are using some methods and techniques to revitalize the districts. One of the famous districts which have been successfully revitalized is Silahtaraga power plant in the golden horn district (figure 3 ). The following paragraph will explain how this area revitalized.

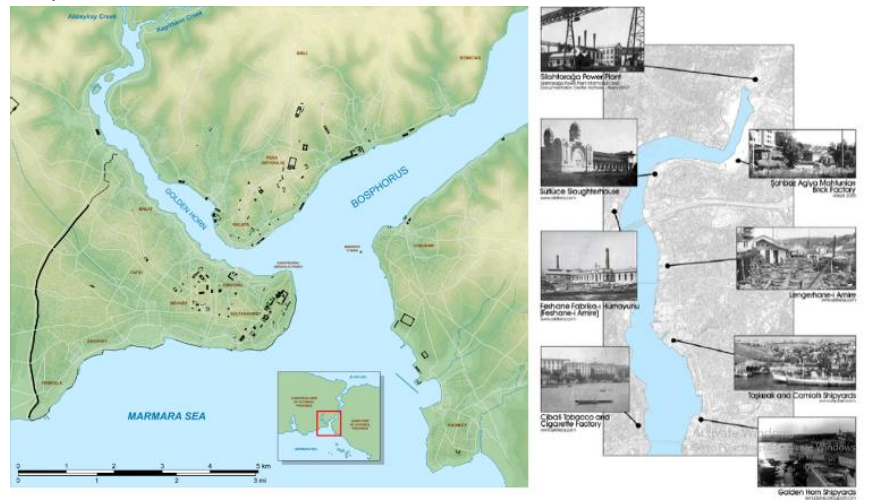

Figure 3. Golden Horn and important industrial districts (Aksoy, 2007).

The choice of this site for the power plant was probably influenced as much by the need for proximity to other industrial facilities as by its strategic location within the city walls at the heart of the busy economic life of the Golden district.

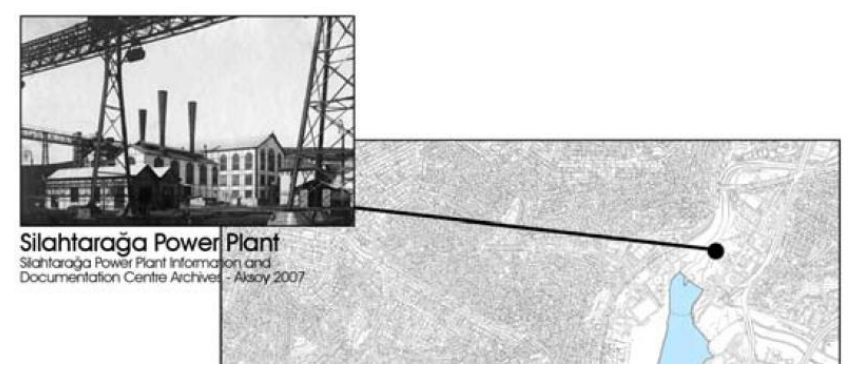

Figure 4. The place of Silahtaraga power plant in golden horn district.

Consequently, in the late 1990s the board of Preservation of Cultural and Natural Heritage listed Santralistanbul as a landmark of industrial archaeology in Istanbul. The conservation and revitalization project for Santralistanbul carry out between 2004 and 2007 by the architecture Han Tümertekin, Nevzat Sayın, and Emre Arolat. 


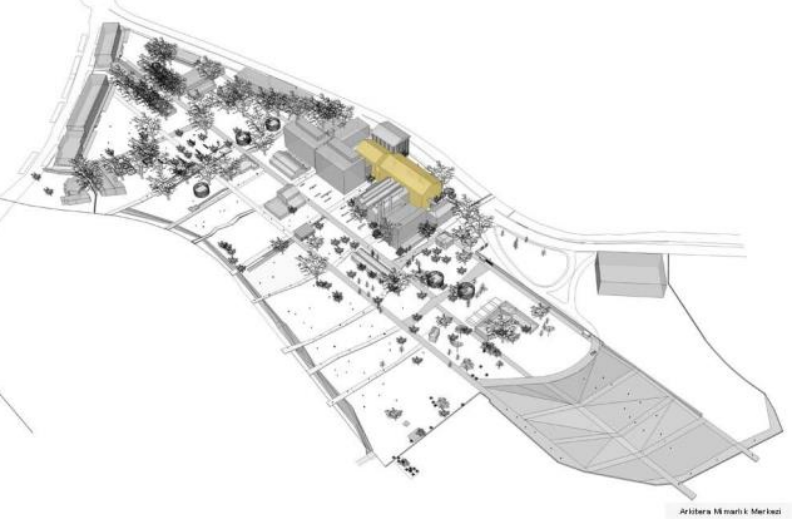

Figure 5. Santralistanbul and the position of museum of energy on it.

The main aim of revitalizing of Santralistanbul was to convert the area for a centre for encouraging production, culture and learning purposes and also preparing an international and interdisciplinary platform for culture and art. To plan entertainment, heritage tourism, and art production. The contemporary art museum (figure 6) which was built on this site has four-story building with amenities for artists, the library and the museum of energy.
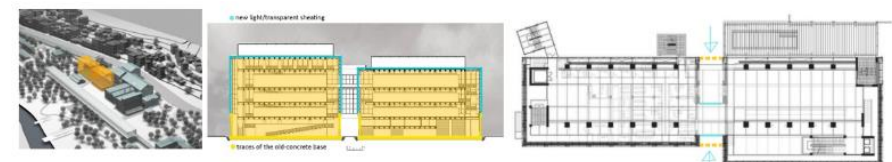

Figure 6. Sabtrlstanbul and the place of contemporary art museum.

\subsection{Analysis of Santralistanbul in order to reuse the Silahtaraga power plant to Energy Museum}

In the Silahtarağa Power Plant area the organization between site's functional zoning which classified to the production units, storage areas, and raw material have been classified and organized with each other in a specific zoning purpose to optimize the maximum energy efficiency of the product. From the other hand, there are lots of administrative buildings around the site. Figure 7 illustrates different building around the site.

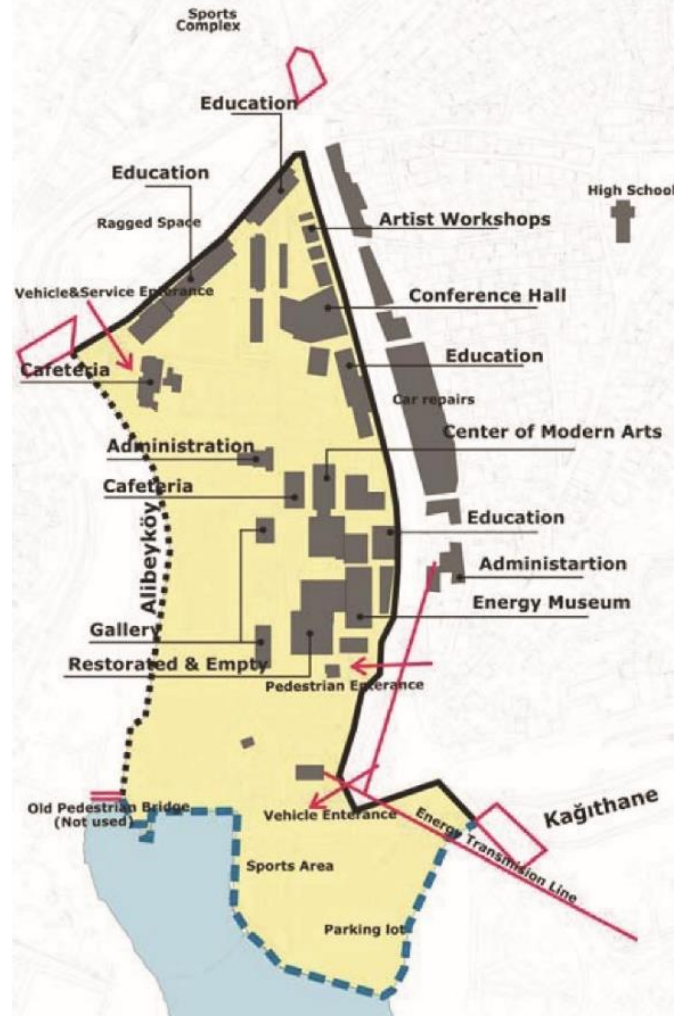

Figure 7. Silahtarağa Power Plant, site plan as it had evolved by 1984 (Brangar, 2004)

Figure 8 reveals the main rooms of the factors which refers boiler rooms and groups of machine in the factory which organized in east-west horizontal axes. Considering the comb-shaped" arrangement

of the original 1910 plan referees the compacts and the necessity for unifying the complex in order to increase the energy efficiency of the factory. 


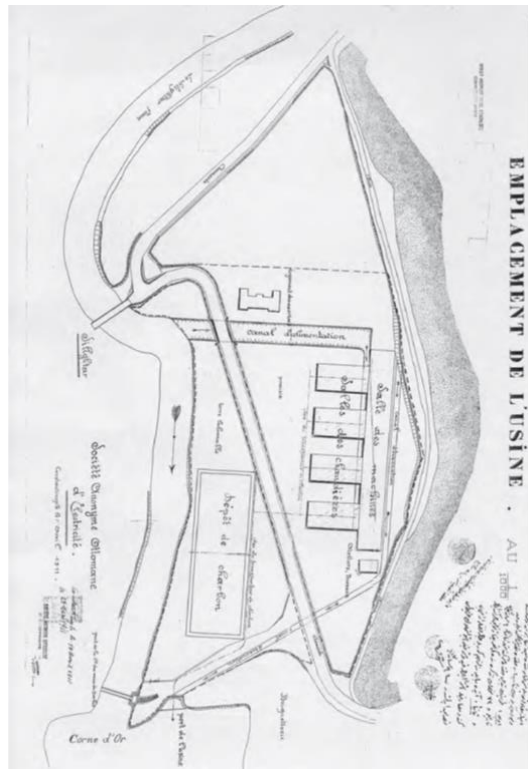

Figure 8. Silahtarağa Power Plant, site plan drawn in 1910.

Considering a reinforced concrete design which later converts to machine hall the other building around the complex were cast-iron construction within large openings. In the case illustrated in figure 9 the arches are in the upper level.

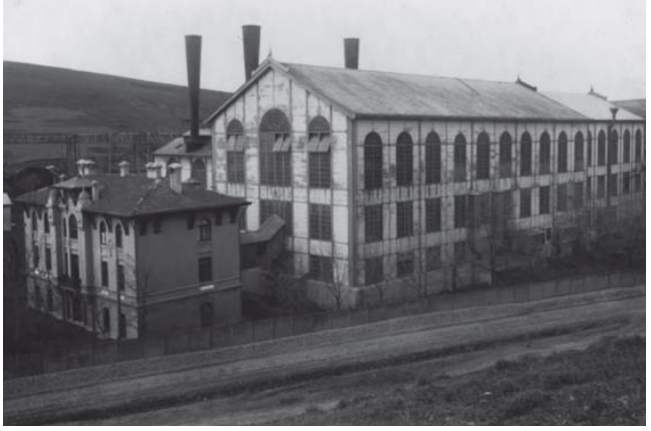

Figure 9. Silahtarağa Power Plant, view of the first machine room and administrative headquarters (Adopted from (Brangar, 2004)

All over the place until the 1920s there were colossal industrial shed grammar omnipresent everywhere.

"This grammar owed its elegance to the ability of the exterior shell to exist independently of the crude internal construction that bore the weight of the gigantic machinery housed within" (BRANGAR, 2004) (See figure 10).

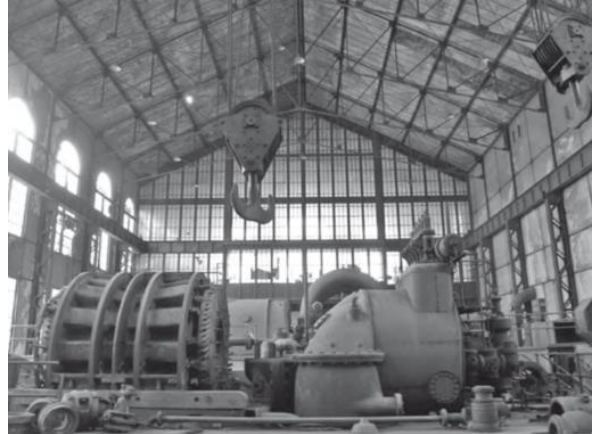

Figure 10. Silahtarağa Power Plant, the main machine hall.

It also should be mentioned that the shop buildings dating from the early stages of construction were small-scale examples of this same cast-iron interior structure with a thin exterior shell language. By understanding the main function and characters inside the site, it's time to focus on the main building which recently converted to recent museum.

\subsection{Energy Museum Architectural analysis}

From the Silahtarağa Power Plant site the housing units and machine halls which were in need of structural reinforcement rehabilitated to energy museum (Brangar, 2004).

The process of regeneration of the building start with a little intervention. In this regard the two machine hall, which are next to each other designed in such a way that to convert to energy museum. The main aim of reusing the building was absorbing impressions and observation.

"Nevertheless, the boiler rooms, which revealed hazardous materials. Like asbestos as well as structural problems, could not be incorporated into the project's museum programs. Rather, their shells were preserved through additional structural reinforcement. While fragments of the interior were retained, and the whole structure was distorted into the new university library" (BRANGAR, 2004).

The existence of the boilers in the central space in an energy museum in the place which recently converted to library is the most astonishing idea in this renovation. Thin exterior shells together with the stairways and service platforms protecting them from the elements. 
Figure 11 reveals the addition of stairway and viewing in the first and second machine hall in which converted into an energy museum.

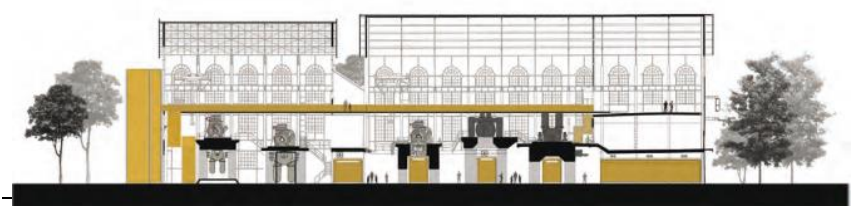

Figure 11. Energy Museum with the addition of a stairway and a viewing.
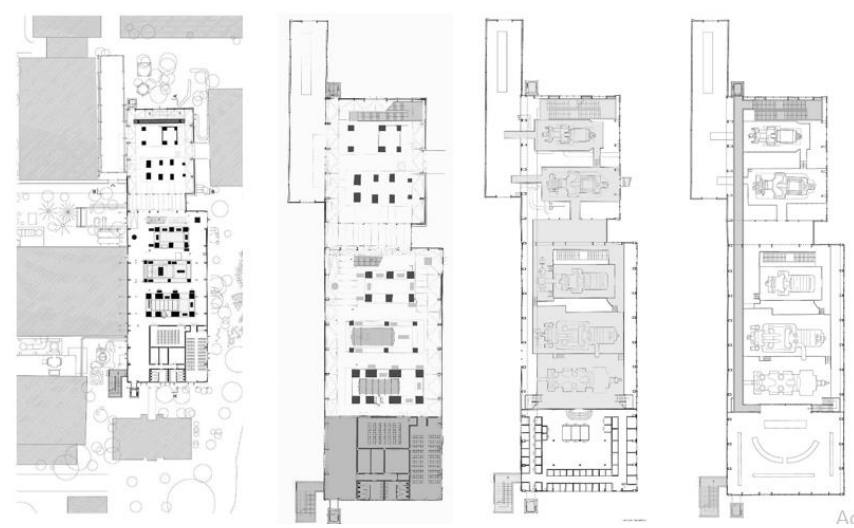

Figure 12. Plans of the Energy Museum.

The building reused by little intervention in order to save the main identity of the building. There were a few additions to the building such as escalators and designing bridges in around the upper floors to have viewed from the top part to inside the museum. The additional part illustrated in figure 13. The approaches for conservation of the building was less integration and the structure are reinforced from inside and the structure is visible from inside.

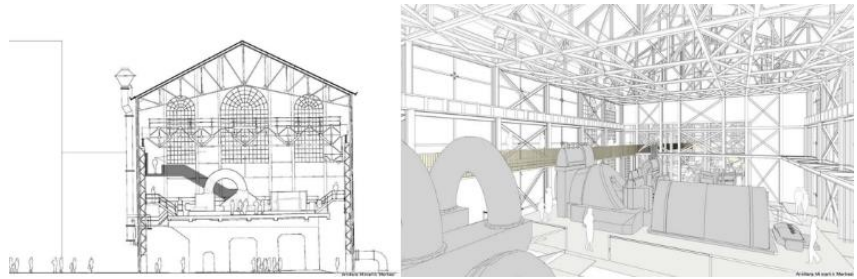

Figure 13. Less intervention and the visibility of structure from inside.

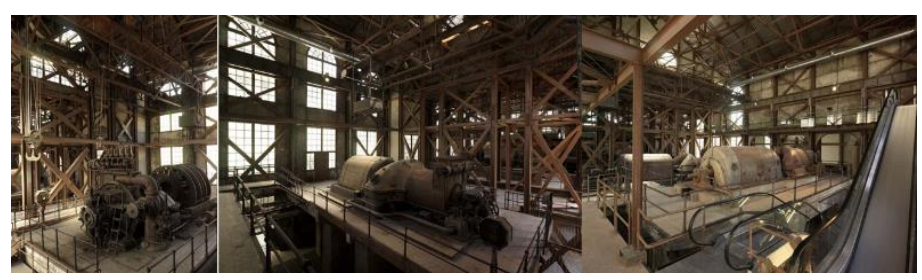

Figure 14. Less intervention and the visibility of structure from inside.

In Energy Museum it's visible to observe that the structure preserved as it was previously. Since the factory was made the machine was the priority for them for this reason the structure of the factory have been organized by considering the structure of the research.

'These current mechanical equipments are transformed into an artificial landscape and the assembly lines transformed into catwalks for people. So that way he provided a new and different platform to show the existing. And another interesting part is that the building was built in the machine scale, but with the new platforms catwalk- it brings human scale to machine scale" (AKSOY, 2007)

According to the principles for conservation in $\mathrm{TICCIH} \mathrm{(2003),} \mathrm{minimum} \mathrm{intervention} \mathrm{has} \mathrm{been}$ done in the original character of the building and has not been disturbed. Added parts include glass material, therefore the structure is visible. There is staircase as well as the ramp inside the building for access to the different floors. Not only the building has been conserved and has become the attraction centre for people, but also the urban context has been preserved according to the changes and conservation.

The following table reveals the value analysis of the energy Museum. It reveals the sensitivity in the contemporary conservation values which is respected to the main rules and objectives of Nizhny-Tagil Charter (AKSOY, 2007). 
Table 3. The degree of success in reusing of energy museum Based on Nizhny-Tagil Charter (AKSOY, 2007).

\begin{tabular}{|c|c|c|}
\hline \multicolumn{2}{|c|}{ Name of the successful example } & \multirow{2}{*}{ 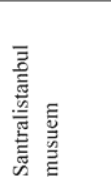 } \\
\hline $\begin{array}{l}\text { Charter } \\
\text { No: }\end{array}$ & Charter Items: & \\
\hline \multirow[t]{2}{*}{ I } & preserving functional integrity & $\checkmark$ \\
\hline & preserving machinery or components & $\checkmark$ \\
\hline \multirow[t]{2}{*}{ II } & Reflecting various industrial processes & $\checkmark$ \\
\hline & examining and assessing all former uses & $\checkmark$ \\
\hline III & Preservation in situ & $\checkmark$ \\
\hline \multirow[t]{3}{*}{ IV } & respecting the significant materials & $\checkmark$ \\
\hline & maintaining original patterns of circulation and activity & $\checkmark$ \\
\hline & being compatible with the original or principal use & $\checkmark$ \\
\hline $\mathrm{V}$ & psychological stability for communities & $\checkmark$ \\
\hline \multirow[t]{4}{*}{ VI } & reversible Interventions & - \\
\hline & minimal impact & - \\
\hline & Documenting unavoidable changes & $\checkmark$ \\
\hline & safely recording and storing elements that are removed & $\checkmark$ \\
\hline VII & $\begin{array}{l}\text { Avoiding reconstruction, or returning to a previous } \\
\text { known state, except for integrity of the whole site }\end{array}$ & $\checkmark$ \\
\hline VIII & $\begin{array}{l}\text { Preserving documentary records, company archives, } \\
\text { building plans, sample specimens of industrial products }\end{array}$ & $\checkmark$ \\
\hline
\end{tabular}

\subsection{Adaptive reuse in museum of energy in Santralistanbul}

Adaptive reuse is the change of functions within an old space. "Adaptive reuse of a building is the process of transforming an existing building to accommodate new uses" (Brooker and Stone, 2008). According to Douglas (2006) there might be different cause of sustainability and conservation. The energy spent and leftover on new constructs for specific purposes could be avoided through the alteration of standing building (Douglas, 2006). Santralistanbul in Turkey Istanbul is one of the best examples of adaptive reuse illustrated in the figures below.

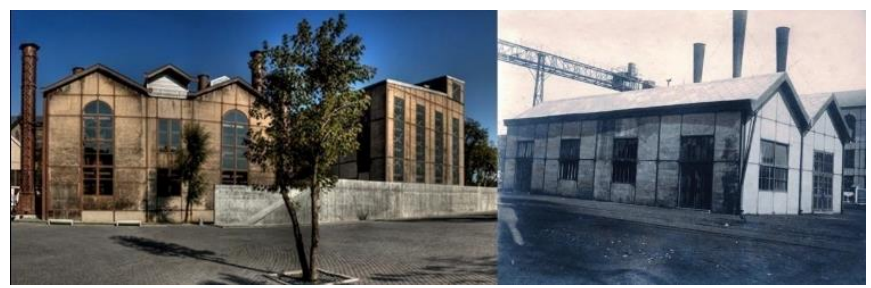

Figure 15. Adaptive reuse in Santralistanbul previous and new building.
By looking carefully for the energy museum to the pictures before and after reuse its visible to conclude that process of reuse have been done perfectly.

\section{Conclusion}

Heritage as a most significant phenomena which transforms human cultural values from the past to the future needs to reserve. Industrial heritage which had a vital effect of human promotion in industrialization period needs also consider to preserve for the future generation. Since the area abandoned and the buildings are going to demolish by the time passing it needs to preserve. Lack of vitality and liability in such a space is the most important factor which increases, the method of rehabilitation in such a place. In the period of industrialization in Golden Horn lots of industrial district and buildings have been built. Santralistanbul as one of this district built with the aim of producing electricity power for the factories and even for residential houses around the Istanbul. The area has been rehabilitated by a group of architects with the purpose of educational and artistic activities. One of the important buildings which was the main focus of this research named as energy museum has been successful reuse from producing electricity to the energy museum. The method of the intervention was in such a way that to have less effect of the body and structure of the building. Therefore, the identity of the building fully preserved.

\section{Acknowledgment}

This research did not receive any specific grant from funding agencies in the public, commercial, or non-for-profit sectors.

\section{References}

Aksoy, A. (ed). (2007) Silahtarağa Elektrik Santrali: 1910-2004, İstanbul Bilgi Üniversity Press.

Brangar, S.Y. (2004) Silahtaraga Elektrik Santrali'nin Korunmasi ve Yeniden Kullanimina Yönelik Oneriler". Yildiz Technical University. 
Brooker, B. G., \& Stone, S. S. (2008) Basics interior architecture 02: Context \& environment. AVA Publishing; illustrated edition edition.

Bullen, P., \& Love, P. (2006) Adaptive Reuse of Historic Heritage buildings. Department of Construction management school of Built Environment Curtin University, Perth Australia.

Burley, J. and Loures, L. (2008) Conceptual Landscape Design Precedent: Four Historic Sites Revisited. Proceedings of the 1st WSEAS International Conference on Landscape Architecture, Algarve, Portugal, June 11-13, 2008, 11-16.

Choay, F. (1992). L'allégorie du patrimoine. Paris: Sevil.

Kuhl, B. (2004). Questões Teóricas Relativas à Preservação da Arquitectura Industrial. In: Revista Desígnio, 1 (1):101-102.

Nizhny Tagil Charter for the Industrial Heritage. (2003) $\mathrm{TICCIH}$ (The International Committee for the Conservation of the Industrial Heritage).

Trinder, B. (1992) The Blackwell Encyclopedia of Industrial Archaeology, Oxford: Blackwell Publishers pp172-173.

Turker, O. (2013) Lecture Notes Inar 569: sustainability in Interiors. Faculty of Architecture, Eastern Mediterranean University Famagusta North Cyprus (via Mersin 10 Turkey).

Şimsek, E. (2006) Endüstri yapılarının kültürel miras olarak degerlendirilmesi: Izmir Liman arkası bölgesi örnegi, unpublished MS thesis submitted to the Graduate School of Natural and Applied Sciences of Dokuz Eylül Üniversitesi, İzmir

R. Shipley, S. Utz, and M. Parsons. (2006) Does Adaptive Reuse Pay? A Study of the Business of Building Renovation in Ontario, Canada (PDF). International Journal of Heritage Studies, 12(6), pp. 505-520.

Hurol, Y, Yuceer, H., \& Basarir, H. (2015) Ethical Guidelines for Structural Interventions to SmallScale Historic Stone Masonry Buildings.
Selfslagh, B. (2002) What future for our heritage? In: Heritage and Sustainable Development Council of Europe, Naturopa. Belgium: Bietlot Gilly.

United Nations Scientific and cultural Organisation.

(1972) Convention concerning the protection of the world cultural and natural heritage. Adopted by the general conference at its seventeenth session Paris.

Cascal, S. (2007) The Adaptive Reuses of Buildings: Remembrance or Oblivion? Argentine/ Argentina.

Orbasli, A. (2009) Re-using Existing Buildings towards Sustainable Regeneration. School of Architecture: place and Culture Identity Group Working Paper.

City of Petersburg City Code. (2007) Adaptive Reuse of Historic Buildings Overlay. Chapter 16, land Department Regulation section 16.30020. José María Fuentes. (2010) Methodological bases for documenting and reusing vernacular farm architecture, Journal of Cultural Heritage, Volume 11, Issue 2, April-June, Pages 119-129

The Athens Charter. (1931) For the Restoration of Historic Monuments. ICOMOS.

The Burra Charter. (1999) The Australia ICOMOS Charter for places of cultural significance. International council on monuments and sites.

The Venice Charter. (1964) International Charter for the Conservation and Restoration of Monuments and sites.

Yerliyurt, B. and Hamamcıoğlu, C. (2005) Entertainment and Culture Based Marketing of Cities in the Unifying World; Golden Horn Culture Valley Project, Istanbul. AESOP Congress Vienna-2005.

Douglas, J. (2006) Building Adaptation, London: Butterworth-Heinemann Publishing. 